\title{
Characterization of TLR2, NOD2, and related cytokines in mammary glands infected by Staphylococcus aureus in a rat model
}

\author{
Heng Wang ${ }^{1,2}$, Guangtao $Y u^{1,2}$, Hui Yu ${ }^{1,2}$, Mingjie Gu ${ }^{1,2}$, Jun Zhang ${ }^{1,2}$, Xia Meng ${ }^{1,2}$, Zongping Liu ${ }^{1,2}$, \\ Changwei Qiu ${ }^{3}$ and Jianji Li ${ }^{1,2^{*}}$
}

\begin{abstract}
Background: Staphylococcus aureus causes subclinical mastitis as well as persistent and chronic infections in cattle. Bovine mastitis induced by S. aureus is often refractory to antibiotic treatment. Local innate immune defenses play an important role in eliminating the invading bacteria. TLR2 and NOD2 are important pathogen recognition receptors, but their functions have not been investigated in the context of early stages of mastitis. The present study examined TLR2, NOD2, and related cytokines in mammary glands infection induced by S. aureus at early stages in a rat mastitis model.
\end{abstract}

Findings: All inoculated mammary glands developed mastitis. Acute changes were induced in mammary tissues infected with $S$. aureus at early stages and then chronic infections persisted until the end of the experiment. TLR2 and NOD2 mRNA expression increased significantly after inoculation with $S$. aureus. The expression levels of cytokine mRNAs, including TNF-a, IL-1 $\beta, I L-6, I L-10$, and CXCL1, also increased. TGF- $\beta 1$ expression was suppressed at early phase and IFN- $\gamma$ mRNA expression increased significantly at a later stage.

Conclusions: Mammary innate immune responses were activated after $S$. aureus inoculation. TLR2, NOD2, and inflammatory cytokines (TNF- $a, I L-1 \beta, I L-6, C X C L 1, I L-10, T G F-\beta 1$, and IFN- $\gamma$ ) are involved in the response to mastitis induced by S. aureus.

Keywords: Cytokine, Innate immune reaction, NOD2, Rat mastitis, S. aureus, TLR2

\section{Findings}

Staphylococcus aureus causes infections in humans and animals $[1,2]$. The pathogen often leads to subclinical bovine mastitis and tends to develop into persistent and chronic infections [3, 4]. Long-term infection causes reduced milk production, resulting in economic loss for dairy producers [5]. One possible mechanism of chronic infection is that the bacteria survive in the host phagocytes and some non-phagocytic cells, including mammary epithelial cells, where an effective concentration of antibiotics can not develop. Innate and acquired immune responses may also be not provoked effectively. S. aureus

\footnotetext{
*Correspondence: yzjjli@163.com

'College of Veterinary Medicine, Yangzhou University, Yangzhou, Jiangsu 225009, China

${ }^{2}$ Jiangsu Co-innovation Center for Prevention and Control of Important Animal Infectious Diseases and Zoonoses, Yangzhou, Jiangsu 225009, China Full list of author information is available at the end of the article
}

vaccines only have marginal benefit in alleviating the duration and severity of clinical symptoms [6]. Potential mechanisms of immune responses in mammary tissues are not well understood and immune suppression may exist.

Innate immunity is the first line of defense against pathogens and body injury, which is triggered by recognition of pathogen-associated molecular patterns (PAMPs) by pattern recognition receptors (PRRs) [7]. PRRs include Nod-like receptors (NLRs), which mediate cytosolic recognition of microbial molecules and promote their clearance [7-9], and Toll-like receptors (TLRs), which are located at the cell surface or within endosomal membranes and recognize a wide range of microbial molecules such as lipopolysaccharide (LPS), peptidoglycan, lipoteichoic acid, flagellin, and zymosan [8, 10, 11]. NOD2 senses muramyl dipeptide (MDP), which is a conserved structure in bacterial peptidoglycan (PGN) [12]. TLR2 recognizes

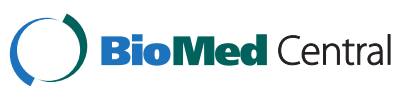

(c) 2015 Wang et al.; licensee BioMed Central. This is an Open Access article distributed under the terms of the Creative Commons Attribution License (http://creativecommons.org/licenses/by/4.0), which permits unrestricted use, distribution, and reproduction in any medium, provided the original work is properly credited. The Creative Commons Public Domain Dedication waiver (http://creativecommons.org/publicdomain/zero/1.0/) applies to the data made available in this article, unless otherwise stated. 
lipoteichoic acid (LTA) and PGN from Gram-positive bacteria, and lipoproteins from Gram-negative bacteria $[8,13]$.

Experimental animal models are useful research tools to study mastitis [14]. Chandler [15] first reported experimental mastitis in a mouse model and mouse models have been employed to evaluate pathophysiology of mastitis $[14,16]$. Rat models were introduced to study mastitis because larger teat channels facilitate bacterial inoculation [17]. The present study aims to reveal the characteristics of TLR2, NOD2, and related cytokines in mammary glands against mastitis induced by $S$. aureus at an early stage in a rat mastitis model.

S. aureus (YZ20108) was previously isolated and identified from a dairy cow with persistent and recurrent mastitis. The bacteria were cultured in Luria-Bertani broth (LB) at $37{ }^{\circ} \mathrm{C}$ and harvested at $\log$ phase. The number of colony-forming units (CFU) was determined by serial dilution and plate count method.

Pregnant Wistar rats, $\mathrm{n}=84$, weighing $275 \pm 25 \mathrm{~g}$, were purchased from the Laboratory Animal Center of Yangzhou University, China. All the rats were raised in plastic cages with sterilized saw dust, temperature of $23 \pm 2{ }^{\circ} \mathrm{C}$ and relative humidity of $50 \pm 5 \%$. They were fed with commercial diet and had free access to water ad libitum. Rats were randomly divided into two groups: experimental group $(\mathrm{n}=42)$ and control group $(n=42)$. L4 and R4 abdominal mammary glands of rats in experimental group were inoculated with $0.1 \mathrm{ml} \mathrm{S}$. aureus, containing $2 \times 10^{7} \mathrm{CFU} / \cdot \mathrm{ml}$ on the 4th day after parturition while the control group with the same volume of physiological saline. The outline of inoculation is as follows: rats were anesthetized with $2 \%$ pentobarbital sodium solution by intraperitoneal injection $(0.2 \mathrm{ml} / 100 \mathrm{~g}$ body weight). After anesthesia, the body surface was cleaned and disinfected. Then a 33-gauge needle equipped with $1 \mathrm{ml}$ syringe was inserted into the mammary duct of $\mathrm{L} 4$ or $\mathrm{R} 4$ and $0.1 \mathrm{ml} S$. aureus or sterile physiological saline was administrated to experimental or control rats, respectively. six rats from each group were euthanized with by cervical dislocation after anesthesia by $2 \%$ pentobarbital sodium injection prior to inoculation $(0 \mathrm{~h})$ and then at $6,12,24,48,72$, and $96 \mathrm{~h}$ post inoculation (pi). Mammary tissue samples were aseptically collected and prepared for bacterial counts, histopathological examination, and molecular analyses. All the experiments were conducted in accordance with the Guide for the Care and Use of Laboratory Animals of the National Research Council. The animal care and use committee of Yangzhou University approved all experiments and procedures.

To quantify the level of infection in mammary glands, mammary tissues were aseptically collected, weighed, and homogenized with sterile physiological saline $(1: 10, \mathrm{~W}: \mathrm{V})$. Suspensions were centrifuged at $10000 \mathrm{rpm}$ for $5 \mathrm{~min}$ at
$4{ }^{\circ} \mathrm{C}$ to discard fat and supernatant. Sediments were suspended and shaken thoroughly. Homogenates were serially diluted in physiological saline, plated on nutrient agar containing $5 \%$ sheep blood and cultured at $37{ }^{\circ} \mathrm{C}$. Bacterial CFU was counted and the level of infection was estimated by CFU per $100 \mathrm{mg}$ of mammary tissue.

Mammary tissues were collected at 0 (prior to inoculation), 6, 12, 24, 48, 72, and $96 \mathrm{~h}$ pi and fixed in $10 \%$ neutral formalin for histopathological examination. Fixed tissues were embedded in paraffin and cut into $5 \mu \mathrm{m}$ continuous sections and stained by hematoxylin-eosin (H\&E).

The extraction of total RNA and real-time fluorescence quantitative polymerase chain reaction (PCR) reaction were performed as previously described [11]. The sequences of primers are listed in Table 1 . The reaction was conducted in triplicate for each sample and the mean value was used to calculate mRNA expression levels. Six samples of each group were measured at each time point. The fold changes for gene expression were calculated with the relative quantification method and Gapdh was applied as a housekeeping gene. The average $\mathrm{dCt}$ of samples collected at $0 \mathrm{~h}$ was used as the calibrator for each sample.

All statistical analyses were performed using IBM SPSS Statistics 20 (Japan). Data was expressed as mean \pm SE

Table 1 Sequences, amplification product size, and GenBank accession number of amplification genes of rats

\begin{tabular}{|c|c|c|c|}
\hline Gene & Primer sequence $\left(5^{\prime}\right.$ to $\left.3^{\prime}\right)$ & $\begin{array}{l}\text { Product } \\
\text { (bp) }\end{array}$ & $\begin{array}{l}\text { Accession } \\
\text { number }\end{array}$ \\
\hline \multirow[t]{2}{*}{ Gapdh } & F:CCAGCAAGGATACTGAGAGCAA & 101 & NM_017008.4 \\
\hline & R:GGATGGAATTGTGAGGGAGATG & & \\
\hline \multirow[t]{2}{*}{ TLR2 } & F:CAAACTGGAGACTCTGGAAGCA & 120 & NM_198769.2 \\
\hline & R:AGGTAGCTGTCTGGCCAGTCA & & \\
\hline \multirow[t]{2}{*}{ NOD2 } & F: ACAAAGACGCCGACACTATACTG & 241 & NM_001106172.1 \\
\hline & R: TCAAGGAGGAACTGGAAGACG & & \\
\hline \multirow[t]{2}{*}{ TNF-a } & F: GTAGCCCACGTCGTAGCAA & 217 & NM_012675.3 \\
\hline & R: AAGTGGCAAATCGGCTGAC & & \\
\hline \multirow[t]{2}{*}{$\mathbb{I L}-1 \beta$} & F:GCAATGGTCGGGACATAGTT & 152 & NM_031512.2 \\
\hline & R:GACTTGGCAGAGGACAAAGG & & \\
\hline \multirow[t]{2}{*}{$\| \mathrm{L}-6$} & F: CACAAGTCCGGAGAGGAGAC & 168 & NM_012589.2 \\
\hline & R: ACAGTGCATCATCGCTGTTC & & \\
\hline \multirow[t]{2}{*}{ CXCL1 } & F:GGCGGAGAGATGAGAGTCTG & 182 & NM_030845.1 \\
\hline & R:AGGCATTGTGCCCTACAAAC & & \\
\hline \multirow[t]{2}{*}{$\mid \mathrm{L}-10$} & F:CACTGCTATGTTGCCTGCTCTTACT & 73 & NM:_012854.2 \\
\hline & R: TTATTGTCACCCCGGATGGA & & \\
\hline \multirow[t]{2}{*}{ TGF- $\beta$} & F:CAACAATTCCTGGCGTTACCTT & 121 & NM_021578.2 \\
\hline & R:CTGTATTCCGTCTCCTTGGTTCA & & \\
\hline \multirow[t]{2}{*}{$\mathrm{IFN}-\gamma$} & F: AGGAACTGGCAAAAGGACG & 196 & NM_138880.2 \\
\hline & R: CGAACTTGGCGATGCTCAT & & \\
\hline
\end{tabular}




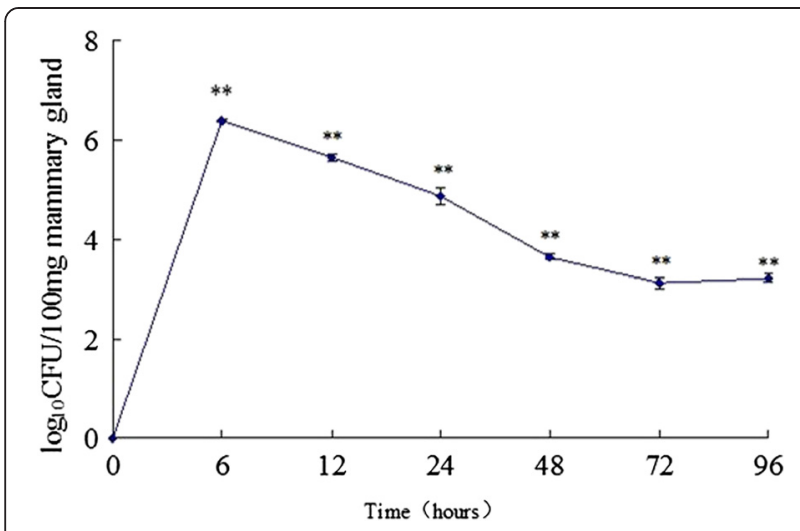

Fig. 1 Bacterial counts change in mammary tissues from experimental group inoculated with S. aureus by $2 \times 10^{6} \mathrm{CFU}$ at different time points. Data were shown by $\log _{10}$ colony-forming units per $100 \mathrm{mg} \pm$ (SE) of mammary tissue. ${ }^{* *} P<0.01$

except the bacterial count in mammary tissue, which was converted to $\log _{10}$ to keep a normal distribution for statistical analyses. Differences were considered significant at $P<0.05$ analyzed by ANOVA and followed by Bonferroni post hoc test.

The results of bacterial counts showed that $S$. aureus were present in all inoculated mammary glands throughout the study. The quantity of $S$. aureus in the mammary glands peaked at $6 \mathrm{~h}$ pi and then decreased gradually until $96 \mathrm{~h}$ pi (Fig. 1). Bacterial colonization in mammary tissues was not found in control group.
In experiment group, histopathological examination revealed enlarged mammary alveoli and appearence of polymorphonuclear cells (PMNs) in the intralobular ducts, alveoli, and interlobular connective tissues at $6 \mathrm{~h}$ pi (Fig. 2a). PMNs infiltrated into the mammary alveoli at $12 \mathrm{~h} \mathrm{pi}$, along with secretory units, round concretions of casein, and cellular debris. Destruction of epithelial cells was seen in some acini (Fig. 2b). At $24 \mathrm{~h} \mathrm{pi}$, inflammation had further developed, and more neutrophils, lymphocytes, and plasma cells appeared in the mammary alveoli and intralobular connective tissues, accompanied with epithelial cells damage and round concretions of casein in alveoli (Fig. 2c). Mammary tissue structure was damaged and alveoli developed atrophy, with inflammatory cells distributed in the alveoli at $48 \mathrm{~h}$ pi (Fig. 2d). At $72 \mathrm{~h}$ and $96 \mathrm{~h}$, inflammatory cells decreased gradually, mammary alveoli atrophied. No pathological changes were observed in the control group (Additional file 1).

Intramammary inoculation with $S$. aureus elicited significant changes in the mRNA levels of TLR2, NOD2, and some cytokine genes in mammary glands of experimental group. Compared to pre-inoculation levels of mammary samples at $0 \mathrm{~h}$, the TLR2, NOD2, and TNF- $\alpha$ mRNA levels of mammary samples in experimental group increased gradually at 12 and $24 \mathrm{~h}$ pi, peaked at $48 \mathrm{~h}$ pi and declined at 72 and $96 \mathrm{~h}$ pi (Fig.3a- c). TLR2 is a crucial immune recognizable receptor activated by $S$. aureus infection in mammary tissue $[18,19]$. Our study supports the hypothesis that TLR2 plays an important

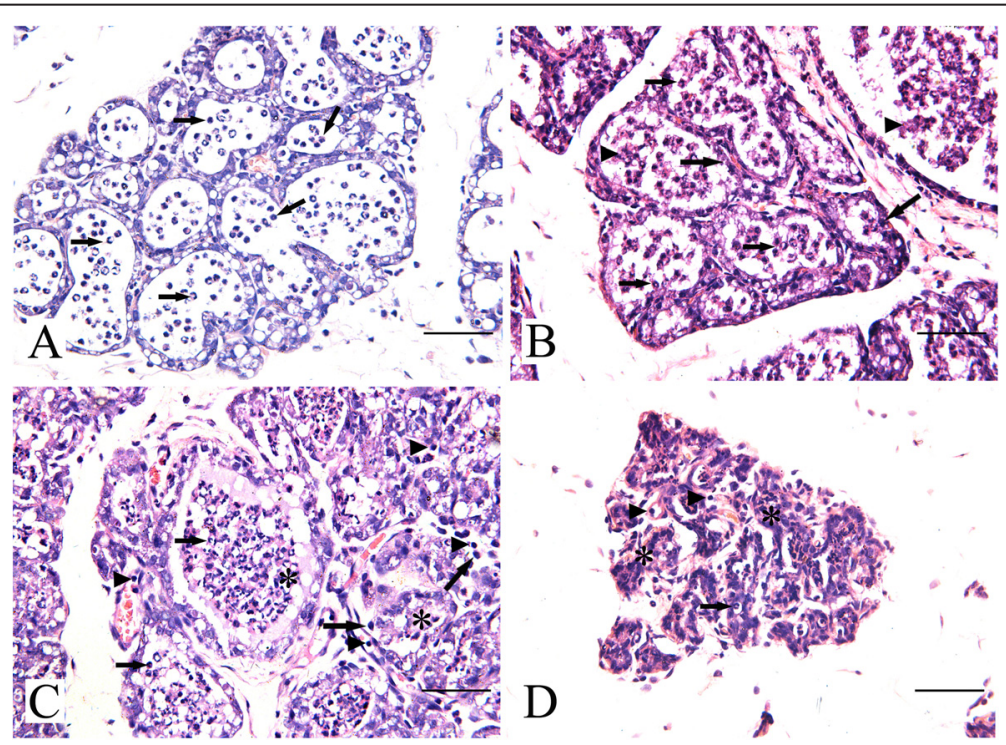

Fig. 2 Histopathological findings of mammary glands inoculated with S. aureus. H\&E stain. Bar $=50 \mu$ m. a PMNs predominately neutrophils appeared in the intralobular ducts, alveoli, and interlobular connective tissues at $6 \mathrm{~h}$ pi (arrow). b Secretory units (arrowhead), epithelial cells debris (large arrow) mixed with neutrophils (small arrow) in acini at $12 \mathrm{~h}$ pi. c Increased number of neutrophils (small arrow), lymphocytes (arrowhead), and plasma cells (large arrow) appeared in the mammary alveoli, accompanied with epithelial cells, and casein (asterisk) at $24 \mathrm{~h}$ pi. d Atrophy of acini (asterisk) with netrophils (arrow) and lymphocytes (arrowhead) in the mammary alveoli and intralobular connective tissues at $48 \mathrm{~h}$ pi 

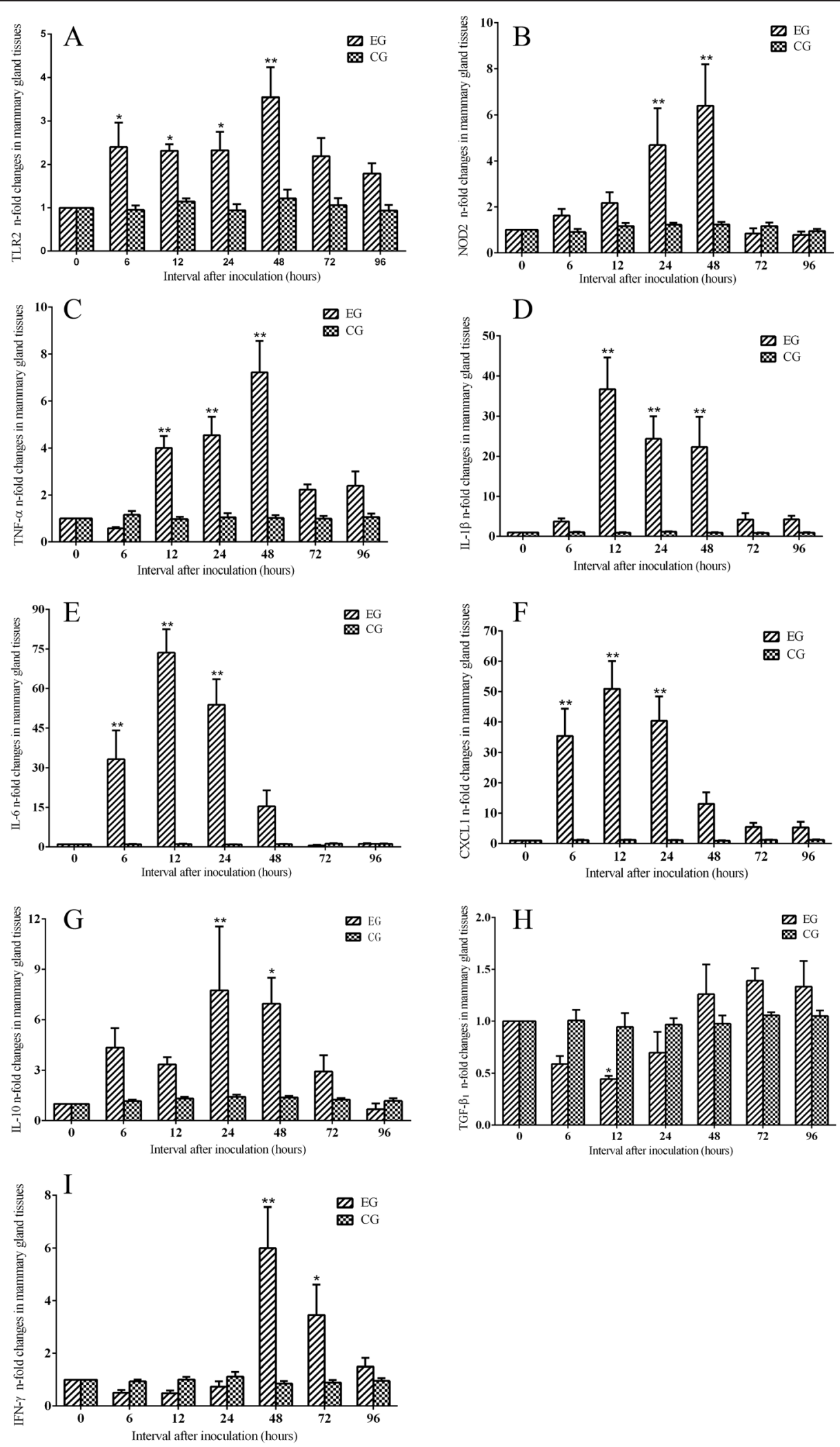

Fig. 3 Fold changes (n-fold) of (a) TLR2, (b) NOD2, (c) TNF- $a$, (d) IL-1 $\beta$, (e) IL-6, (f) CXCL1, (g) IL-10, (h) TGF- $\beta 1$, and (i) IFN- $y$ mRNA expression in the mammary tissue of rats after intramammary inoculation with S. aureus (experimental group, EG), or PBS (control group, CG). Statistically significant differences between the experimental group and control group are indicated $\left(* P<0.05\right.$, $\left.{ }^{*} P<0.01\right)$ 
role at the early inflammation induced by $S$. aureus in mammary glands. Meanwhile, PMNs migrated into the mammary tissues, which may enhance the ability of clearing the bacteria. We also find an association of PMNs migration into the mammary tissues with the higher expression of NOD2, which may contribute to enhancing innate immune response and accelerate elimination of bacteria. The higher NOD2 expression in the mammary tissues is an indication of the S. aureus recognition and immune response against the pathogen. TNF- $\alpha$ early up-regulation is crucial for the prompt defense against invading pathogens. IL- $1 \beta$ plays an important role in host immune reaction by taking part in inducing neutrophil recruitment to control the $S$. aureus infection [20]. In our study, mRNA level of IL-1 $\beta$ also increased sharply after inoculation $6 \mathrm{~h}$ pi and peaked at $12 \mathrm{~h}$ pi (Fig. 3d), which was in accord with histological examination characterized by plenty of PMNs infiltrating the mammary glands. The mRNA levels of IL- 6 and CXCL1 were up-regulated significantly and peaked at $12 \mathrm{~h}$ pi and then decreased gradually at 24 and $48 \mathrm{~h}$ pi (Fig. 3e and f). IL-6 is a pleiotropic cytokine, which involved in inflammatory responses, differentiation, activation of lymphocytes, and production of immunoglobulins [21]. It is supposed that a swift and strong expression level of IL-6 mRNA induces migration of PMNs and triggers the activation of transcription including TNF$\alpha$ and IL-1 $\beta$. The mRNA expression of CXCL1, analog of IL-8 [22], increased dramatically after inoculation. It suggested that CXCL1 was activated and could attract PMNs migration into the inflammatory location and eliminate the invading pathogens. In addition, gene expression of TNF- $\alpha$, and IL-1 $\beta$ increased more slowly than CXCL1 in mammary tissues, which suggested that infiltrated PMNs contributed to the production of TNF- $\alpha$ and IL-1 $\beta$ after CXCL1 activation. The expression of IL-10 mRNA in mammary samples increased significantly at 24 and $48 \mathrm{~h}$ pi (Fig. $3 \mathrm{~g}$ ). However, the transcriptional level of TGF- $\beta 1$ dropped sharply at $12 \mathrm{~h}$ pi in experimental group and then increased slowly (Fig. $3 \mathrm{~h}$ ). It suggested that TGF- $\beta 1$ was suppressed at the initial phase of mammary infection. IFN- $\gamma$ is a cytokine that is very important for innate and adaptive immunity against infection of virus and intracellular bacteria [23]. The mRNA expression of IFN- $\gamma$ decreased slightly at 6 and $12 \mathrm{~h}$ pi, but increased dramatically at $48 \mathrm{~h}$ pi and then declined gradually at 72 and $96 \mathrm{~h} \mathrm{pi} \mathrm{(Fig.} \mathrm{3i).} \mathrm{It}$ revealed that elevate expression of IFN- $\gamma$ in later stage was probably related with $S$. aureus invasion and survival in the tissue cells as time went on, and had immunostimulatory, and immunomodulatory effects.

\section{Conclusion}

The local innate immune response of mammary glands was swiftly activated after $S$. aureus inoculation during the initial stage of infection, characterized by up-regulation of gene expression of TLR2, NOD2, TNF- $\alpha$, IL-1 $\beta$, IL-6, and CXCL1. Additionally, anti-inflammatory cytokine IL-10 took part in the inflammation modulation and TGF- $\beta 1$ was suppressed during the $S$. aureus infection. Considerable quantity of $S$. aureus that survived in the mammary tissues led to persistent inflammation, and IFN- $\gamma$ played a role in the later inflammation.

\section{Additional file}

\section{Additional file 1: Microphotographs of mammary glands inoculated} with physiological saline (A, B). H\&E stain. Bar $=50 \mu \mathrm{m}$.

\section{Abbreviations}

CFU: Colony-forming units; IFN: Interferon; IL: Interleukin; LPS: Lipopolysaccharide; LTA: Lipoteichoic acid; MDP: Muramyl dipeptide; NLRs: Nod-like receptors; PAMPs: Pathogen-associated molecular patterns; PCR: Polymerase chain reaction; PGN: Peptidoglycan; PMNs: Polymorphonuclear cells; PRRs: Pattern recognition receptors; TGF- $\beta$ : Transforming growth factor- $\beta$; TLRs: Toll-like receptors; TNF-a: Tumor necrosis factor-a.

\section{Competing interests}

The authors declare that they have no competing interests.

\section{Authors' contributions}

HW, GTY and JJL designed, and conducted the research. HY, MJG, JZ, XM, and CWQ helped to perform the experiments. HW, GTY, XM, and JJL analyzed the results. ZPL provided the convenient of apparatuses and gave some constructive proposals. HW and J J drafted the manuscript. All authors read and approved the final manuscript. HW and GTY contributed equally to this work.

\section{Acknowledgements}

The investigation was supported by the National Science Foundation of China (No.31072176, 31302151, 31101864), Youth Natural Foundation of Jiangsu Province (No.BK2012265), Jiangsu Province Postdoctoral Science Foundation Funded Project (No.0901054C), Priority Academic Program Development of Jiangsu Higher Education Institutions (PAPD) and Yangzhou University Overseas Research \& Training Program for Prominent Young \& Middle-aged Teachers and Presidents. We thank Philip R. Hardwidge (College of Veterinary Medicine, Kansas State University) for English correction of the manuscript.

\section{Author details}

${ }^{1}$ College of Veterinary Medicine, Yangzhou University, Yangzhou, Jiangsu 225009, China. ${ }^{2}$ Jiangsu Co-innovation Center for Prevention and Control of Important Animal Infectious Diseases and Zoonoses, Yangzhou, Jiangsu 225009, China. ${ }^{3}$ College of Animal Science and Veterinary Medicine, Huazhong Agricultural University, Wuhan, Hubei 430070, China.

Received: 20 August 2014 Accepted: 16 May 2015

Published online: 20 May 2015

\section{References}

1. Lundberg A, Aspan A, Nyman A, Unnerstad HE, Waller KP. Associations between bacterial genotype and outcome of bovine clinical Staphylococcus aureus mastitis. Acta Vet Scand. 2014;56:2.

2. Pu W, Su Y, Li J, Li C, Yang Z, Deng H, et al. High incidence of oxacillin-susceptible mecA-positive Staphylococcus aureus (OS-MRSA) associated with bovine mastitis in China. PLoS One. 2014;9:e88134.

3. Rall VL, Miranda ES, Castilho IG, Camargo CH, Langoni H, Guimaraes FF, et al. Diversity of Staphylococcus species and prevalence of enterotoxin genes isolated from milk of healthy cows and cows with subclinical mastitis. J Dairy Sci. 2014;97:829-37. 
4. Bardiau M, Detilleux J, Farnir F, Mainil JG, Ote I. Associations between properties linked with persistence in a collection of Staphylococcus aureus isolates from bovine mastitis. Vet Microbiol. 2014;169:74-9.

5. Demon D, Breyne K, Schiffer G, Meyer E. Antimicrobial efficacy of intramammary treatment with a novel biphenomycin compound against Staphylococcus aureus, Streptococcus uberis, and Escherichia coli-induced mouse mastitis. J Dairy Sci. 2013;96:7082-7.

6. Nordhaug ML, Nesse LL, Norcross NL, Gudding R. A field trial with an experimental vaccine against Staphylococcus aureus mastitis in cattle. 2. Antibody response. J Dairy Sci. 1994;77:1276-84.

7. Jeong YJ, Kang MJ, Lee SJ, Kim CH, Kim JC, Kim TH, et al. NOD2 and RIP2 contribute to innate immune responses in mouse neutrophils. Immunology. 2014;143:269-76.

8. Philpott DJ, Girardin SE. The role of Toll-like receptors and Nod proteins in bacterial infection. Mol Immunol. 2004;41:1099-108.

9. Philpott DJ, Sorbara MT, Robertson SJ, Croitoru K, Girardin SE. NOD proteins: regulators of inflammation in health and disease. Nat Rev Immunol. 2014;14:9-23.

10. Novak K. Functional polymorphisms in Toll-like receptor genes for innate immunity in farm animals. Vet Immunol Immunopathol. 2014;157:1-11.

11. Shao CY, Wang H, Meng X, Zhu JQ, Wu YQ, Li JJ. Characterization of the innate immune response in goats after intrauterine infusion of $E$. coli using histopathological, cytologic and molecular analyses. Theriogenology. 2012;78:593-604

12. Girardin SE, Travassos LH, Herve M, Blanot D, Boneca IG, Philpott DJ, et al. Peptidoglycan molecular requirements allowing detection by NOD1 and NOD2. J Biol Chem. 2003;278:41702-8.

13. Oliveira-Nascimento L, Massari P, Wetzler LM. The role of TLR2 in Infection and Immunity. Front Immunol. 2012;3:79.

14. Glynn DJ, Hutchinson MR, Ingman W. Toll-like receptor 4 regulates lipopolysaccharide-induced inflammation and lactation insufficiency in a mouse model of mastitis. Biol Reprod. 2014;90:91.

15. Chandler RL. Experimental bacterial mastitis in the mouse. J Med Microbiol. 1970;3:273-82.

16. Trigo G, Dinis M, Franca A, Bonifacio AE, da Costa RM G, Ferreira P. Leukocyte populations and cytokine expression in the mammary gland in a mouse model of Streptococcus agalactiae mastitis. J Med Microbiol. 2009;58:951-8

17. Zhu YM, Miao JF, Fan HJ, Zou SX, Chen WH. Protective effect of CpG-DNA against mastitis induced by Staphylococcus aureus infection in a rat model. Int Immunopharmacol. 2007;7:435-43.

18. Fang L, Wu HM, Ding PS, Liu RY. TLR2 mediates phagocytosis and autophagy through JNK signaling pathway in Staphylococcus aureus-stimulated RAW264.7 cells. Cell Signal. 2014:26:806-14.

19. Yang W, Zerbe H, Petzl W, Brunner RM, Gunther J, Draing C, et al. Bovine TLR2 and TLR4 properly transduce signals from Staphylococcus aureus and E. coli, but S. aureus fails to both activate NF-kappaB in mammary epithelial cells and to quickly induce TNFalpha and interleukin-8 (CXCL8) expression in the udder. Mol Immunol. 2008;45:1385-97.

20. Bernthal NM, Pribaz JR, Stavrakis Al, Billi F, Cho JS, Ramos Rl, et al. Protective role of IL-1 beta against post-arthroplasty Staphylococcus aureus infection. J Orthop Res. 2011;29:1621-6.

21. Wong GG, Clark SC. Multiple actions of interleukin 6 within a cytokine network. Immunol Today. 1988:9:137-9.

22. Rohr-Udilova N, Sieghart W, Eferl R, Stoiber D, Bjorkhem-Bergman L, Eriksson LC, et al. Antagonistic effects of selenium and lipid peroxides on growth control in early hepatocellular carcinoma. Hepatology. 2012:55:1112-21.

23. Czarniecki CW, Sonnenfeld G. Interferon-gamma and resistance to bacterial infections. APMIS. 1993:101:1-17.

\section{Submit your next manuscript to BioMed Central and take full advantage of:}

- Convenient online submission

- Thorough peer review

- No space constraints or color figure charges

- Immediate publication on acceptance

- Inclusion in PubMed, CAS, Scopus and Google Scholar

- Research which is freely available for redistribution

Submit your manuscript at www.biomedcentral.com/submit 